\title{
LIGHTS, JUDGES, ACCESS: \\ How ACTIVE Judicial REVIEW OF DiscretionaRy DECISIONS PROTECTS ACCESS TO GOVERNMENT INFORMATION
}

\author{
VINCENT KAZMIERSKI*
}

This article discusses the role of judicial review in access to information regimes in Canada. It provides a review of recent court decisions that show how the Canadian courts are actively supervising the exercise of administrative discretion over access to information. It argues that although efforts to reform Canada's access to information legislation have so far been met with limited success, the judiciary has provided significant and important scrutiny, providing a key means of enforcing access to information rights in Canada.
Cet article porte sur le rôle du contrôle judiciaire dans l'accès aux régimes d'information au Canada. Il donne un aperçu des récentes décisions judiciaires qui démontrent de quelle manière les tribunaux canadiens supervisent activement l'exercice de la discrétion administrative dans le cas de l'accès à l'information. L'auteur fait valoir que bien que l'effort de réforme des lois sur l'accès à l'information du Canada n'ait eu, jusqu'à présent, qu'un succès limité, la magistrature, quant à elle, a fourni un examen considérable et important, donnant des moyens-clés pour appliquer les droits à l'accès à l'information au Canada.

\section{TABLE OF CONTENTS}

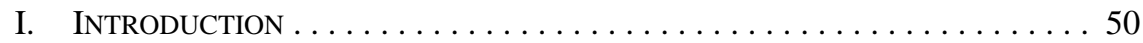

II. REVIEWING THE EXERCISE OF ADMINISTRATIVE DISCRETION

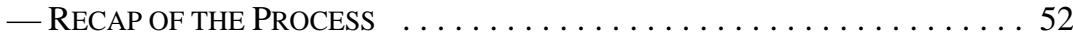

III. ONTARIO (PUBLIC SAFETY AND SECURITY) V.

CRIMINAL LAWYERS' ASSOCIATION . . . . . . . . . . . . . . . . . . 54

A. THE SUPREME COURT'S DISCUSSION OF

ADMINISTRATIVE DisCRETION . . . . . . . . . . . . . . . 56

IV. ATtARAN V. CANADA (Minister of Foreign AFFAIRS) . . . . . . . 62

V. BRONSKILL V. CANADA

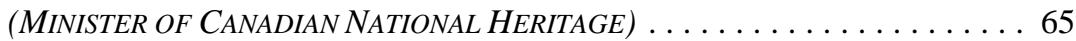

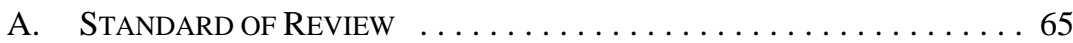

B. The EVIDENCE REQUiREMENT $\ldots \ldots \ldots \ldots \ldots \ldots \ldots \ldots \ldots . \ldots \ldots$

C. DETERMINATION OF WHETHER THE INFORMATION

FITS WITHIN THE EXEMPTION $\ldots \ldots \ldots \ldots \ldots \ldots \ldots . \ldots . \ldots 67$

D. REVIEWING THE EXERCISE OF DISCRETION $\ldots \ldots \ldots \ldots \ldots \ldots 70$

VI. ASSESSING THE IMPACT OF CRIMINAL LAWYERS'

ASSOCIATION, ATTARAN, AND BRONSKILL $\ldots \ldots \ldots \ldots \ldots \ldots \ldots \ldots 72$

VII. CONCLUSION $\ldots \ldots \ldots \ldots \ldots \ldots \ldots \ldots \ldots \ldots \ldots \ldots \ldots \ldots$

Assistant Professor, Department of Law and Legal Studies, Carleton University, Ottawa. My thanks to Darren Pacione for his excellent research assistance. Thank you also to the University of Ottawa Faculty of Law (Civil Law Section) and the University of Saskatchewan College of Law for inviting me to give presentations that provided the genesis of this article. Finally, thanks to Dean Bruce Feldthusen and the University of Ottawa Faculty of Law (Common Law Section) for hosting me as visiting professor while I drafted the final article. 


\section{INTRODUCTION}

1 July 2013 marked the 30th anniversary of the date the federal Access to Information Act came into force. ${ }^{1}$ The anniversary has placed a temporary spotlight on the ongoing calls for legislative reforms to strengthen legislative access frameworks in Canada, particularly the federal Access Act. At the same time, the Supreme Court of Canada's decision in Ontario (Public Safety and Security) v. Criminal Lawyers' Association ${ }^{2}$ has heightened awareness of the importance of access rights with its recognition of a limited constitutional protection of access to information through section 2(b) of the Charter. ${ }^{3}$ While further renewal of legislative access frameworks is necessary, and the recognition of constitutional protection of access rights is commendable, the focus on legislative reform and constitutional protection ignores perhaps the most important factor in protecting our rights to access government information: ongoing and effective supervision of administrative discretion exercised under existing legislative regimes.

The quest to obtain access to government information must inevitably confront the exercise of administrative discretion. Government officials exercise discretion at almost every stage of the access process. Frontline officials are involved in gathering and forwarding information to access coordinators. Access coordinators collect and review the information to determine whether it falls within exemptions for disclosure set out in the governing legislation. Department heads determine whether to exercise their discretion to disclose or refuse disclosure of information pursuant to legislative exemptions. At each stage, government officials make choices that ultimately affect our access to government information.

While many government officials work diligently to ensure that the public enjoys access to the information necessary to maintain accountability within our democratic system, there are clear signs that many others operate less diligently. The growing tendency to delay and resist disclosure of information that should rightfully be released under the provisions of access legislation has been noted by academics and access commissioners alike. Among academics, Alasdair Roberts has warned of this problem for decades. ${ }^{4}$ Information commissioners have been similarly vocal. For example, in 2011, the Information Commissioner of Canada noted that administrative delays were undermining the right to access government information to such an extent that " " $[\mathrm{t}]$ his right is at risk of being totally obliterated because delays threaten to render the entire access regime irrelevant in our current

Access to Information Act, RSC 1985, c A-1 [Access Act].

2010 SCC 23, [2010] 1 SCR 815 [Criminal Lawyers’ Association].

Canadian Charter of Rights and Freedoms, Part I of the Constitution Act, 1982, being Schedule B to the Canada Act 1982 (UK), 1982, c 11 [Charter].

See e.g. Alasdair Roberts, "Retrenchment and Freedom of Information: Recent Experience Under Federal, Ontario and British Columbia Law” (1999) 42:4 Canadian Public Administration 422; Alasdair Roberts, “New Strategies for Enforcement of the Access to Information Act” (2002) 27:2 Queen's LJ 647; Alasdair Roberts, “Administrative Discretion and the Access to Information Act: An Internal Law' on Open Government?” (2002) 45:2 Canadian Public Adminstration 175; Alasdair Roberts, "Spin Control and Freedom of Information: Lessons for the United Kingdom from Canada” (2005) 83:1 Public Administration 1; Alasdair Roberts, Blacked Out: Government Secrecy in the Information Age (New York: Cambridge University Press, 2006). See also, Vincent Kazmierski, “Accessing Democracy: The Critical Relationship between Academics and the Access to Information Act” (2011) 26:3 CJLS 613 [Kazmierski, “Accessing Democracy”]; Stanley L Tromp, Fallen Behind: Canada's Access to Information Act in the World Context (September 2008), online: Canadian FOI Resource Website $<$ http://www3.telus.net/index100/report>. 
information economy." The Commissioner has also raised alarms concerning the tendency of government officials to exercise their discretion to protect information from disclosure rather than releasing it. In her 2010-2011 Annual Report, Commissioner Legault noted:

Far from reflecting the presumption of disclosure inherent in the Access to Information Act, the exercise of discretion in determining which information to disclose has been skewed toward greater protection of information. For example, the percentage of exemptions claimed for national security has increased threefold since 2002-2003. ${ }^{6}$

The warnings issued by academics and information commissioners have also, occasionally, caught the attention of the press. ${ }^{7}$ However, to date, the periodic sounding of alarms by academics, information commissioners, and journalists has failed to mobilize the type of large-scale public outrage needed to cause the offending officials themselves to change their obstructionist behavior. As a result, institutional controls on obstructionist behavior take on a greater importance.

Information commissioners have an important role to play in combatting the failure of government officials to abide by both the letter and spirit of access to information legislation. Thus, for example, the Information Commissioner of Canada has focused much of her recent work on creating incentives for government departments to meet their disclosure obligations in a timelier manner. ${ }^{8}$ Indeed, the Commissioner's strategy appears to have reduced delays in the processing of access requests in many areas. Similarly, the Commissioner can report many successful interventions in which her office convinced government officials to reconsider their discretion and to release information where the disclosure was originally refused. ${ }^{9}$

Ultimately, however, ensuring that government officials properly exercise their discretion pursuant to access legislation also depends on the role of the judiciary in reviewing the exercise of that discretion. This article considers several important recent court decisions that have reviewed the exercise of administrative discretion under discretionary exemptions in access to government legislation. These cases show that Canadian courts have been engaged in active, though not intrusive, supervision of the exercise of administrative discretion in this

5 Information Commissioner of Canada, Out of Time: 2008-2009 Report Cards and Systemic Issues Affecting Access to Information in Canada (Ottawa: Minister of Public Works and Government Services Canada, 2010), online: Information Commissioner of Canada: <http://www.oic-ci.gc.ca/eng/rp-pr_sperep_rap-spe_rep-car_fic-ren_2008-2009.aspx> at 2 [Out of Time]. Information Commissioner of Canada, Paving the Access Ramp to Transparency: Annual Report 20102011 (Ottawa: Minister of Public Works and Government Services Canada, 2011), online: Information Commissioner of Canada <http://www.oic-ci.gc.ca/eng/rp-pr_ar-ra_2010-2011.aspx> at 2.

$7 \quad$ See e.g. WT Stanbury, "Subverting the Access to Information Act: The efforts of Sébastien Togneri and other political staffers," The Hill Times (18 October 2010); "Study ranks Canada's freedom-ofinformation laws dead last,” The Star (9 January 2011), online: Thestar.com <http://www.thestar.com/ news/canada/2011/01/09/study_ranks_canadas_freedomofinformation_laws_dead_last.html>; Karen Kleiss, “Freedom-of-information system ranked last,” Edmonton Journal (11 January 2011), online: Canada.com <http://www2.canada.com/edmontonjournal/news/cityplus_alberta/story.html?id=b9b105 88- 2d0b-409f-ab81-511384f62541\&p=2>; Jim Bronskill, "As federal access law turns 30, advocates say it should cover Parliament,” Maclean's (1 July, 2013), online: Macleans.ca <http://www2. macleans.ca/2013/07/01/as-federal-access-law-turns-30-advocates-say-it-should-cover-parliament/>. See e.g. the extensive use of departmental 'Report Cards' to identify problems with delays in the access process that began with the Out of Time report, supra note 5 at 20.

See e.g. Information Commissioner of Canada, Annual Report 2011-2012 (Ottawa: Minister of Public Works and Government Services Canada, 2012), online: Information Commissioner of Canada <http:// www.oic-ci.gc.ca/eng/annual-reports-rapports-annuel_2011-2012.aspx>. 
area. This active supervision reinforces the requirement that government officials must justify their decisions not to disclose information, thereby shining a light on these decisions. As such, judicial review of these discretionary decisions helps to ensure that our right to access government information is protected within the confines of existing legislative frameworks.

This article briefly outlines the steps in reviewing the exercise of administrative discretion under access to information regimes. Part III considers the way in which the decision of the Supreme Court of Canada in the Criminal Lawyers' Association case has set the stage for this active approach to supervising discretionary decisions and illustrates the way in which several provincial access to information adjudicators have applied the guidelines established in that case. The article considers two more recent decisions taken by the Federal Court of Appeal $^{10}$ and the Federal Court, ${ }^{11}$ in Parts IV and V respectively. These decisions provide additional examples of the active approach that Canadian courts are applying in reviewing the application of discretionary exemptions by government officials. Part VI considers the potential impact of all three cases discussed in the article. While it is too early to conclusively assess their overall impact, these cases suggest that government officials will face significant scrutiny when attempting to refuse disclosure of government information pursuant to discretionary exemptions under access legislation. This scrutiny is welcomed as a means of enforcing existing access rights in Canada while we continue the long wait for the modernization of access legislation in this country. ${ }^{12}$

\section{REVIEWING THE EXERCISE OF ADMINISTRATIVE DiSCRETION - RECAP OF THE PROCESS}

The review of administrative decisions to apply exemptions included in access regimes is a multi-stage process. The first stage is to determine whether the information at issue falls within the legislative exemption. The exemptions in access legislation can be categorized according to two types of features: class-based exemptions versus injury-based exemptions and mandatory exemptions versus discretionary exemptions. Class-based exemptions function such that the simple inclusion of the type of information at issue in the defined class is sufficient to trigger the exemption. Injury-based exemptions, by contrast, require demonstration of the reasonable likelihood of a defined injury arising from potential disclosure of the information in order to trigger the exemption. Mandatory exemptions require exclusion of the information once the information is confirmed to fit in the defined exemption. By contrast, discretionary exemptions allow the decision-maker to choose to disclose the information despite the fact that it fits within a defined exemption.

Attaran v Canada (Minister of Foreign Affairs), 2011 FCA 182, 420 NR 315, leave to appeal refused 34402 (29 March 2012), 434 NR 392 [Attaran].

Bronskill v Canada (Minister of Canadian National Heritage), 2011 FC 983, 395 FTR 165, var'd 2012 FCA 250, 356 DLR (4th) 192, leave to appeal to SCC refused, 35118 (28 March 2013), [2012] SCCA no 509 (QL) [Bronskill].

12 For a brief summary of several failed attempts to reform the federal Access to Information Act see Kazmierski, “Accessing Democracy,” supra note 4 at 618-21. In the most recent attempt to push legislative reform of the federal access legislation, the Information Commissioner of Canada launched an 'open dialogue initiative' in Fall 2012 seeking suggestions for legislative reform. The Information Commissioner of Canada is expected to table a new set of formal recommendations for legislative reform in Fall 2013. See Information Commissioner of Canada, 30th Anniversary, online: Office of the Information Commissioner of Canada <http://www.oic-ci.gc.ca/eng/media-room-salle-media_newsreleases-communiques-de-presse_2013_3.aspx>. 
Section 19(1) of the federal Access Act provides an example of a class-based, mandatory exemption: once the information is determined to fall within the definition of "personal information" found in section 3 of the Privacy Act, the government decision-maker must refuse to disclose the evidence unless it falls within the scope of section 19(2) of the Access Act. ${ }^{13}$ Section 21 of the federal Access Act provides an example of a class-based, discretionary exemption: once the government decision-maker determines that the information fits within the exemption, she may exercise her discretion to decide to disclose the information or to refuse disclosure. ${ }^{14}$ Finally, section 15 of the federal Access Act provides an example of an injury-based, discretionary exemption: the government decisionmaker must first establish that the disclosure of the information "could reasonably be expected to be injurious to the conduct of international affairs, the defence of Canada or any state allied or associated with Canada or the detection, prevention or suppression of subversive or hostile activities." ${ }^{15}$ Having established the reasonable likelihood of the defined injury, the decision-maker can then exercise her discretion to decide to disclose or refuse to disclose the information.

Where decision-makers rely on class-based exemptions, the determination of whether the information falls within the class has been reviewed historically on a standard of correctness. ${ }^{16}$ The decision-maker either correctly determines that the information falls within the exemption or she does not. There is no deference owed to the decision-maker's interpretation of the statutory exemption. However, the reliance on injury-based exemptions typically requires the decision-maker to determine whether there is a reasonable prospect of injury if the information is disclosed. This suggests that a range of determinations of the likelihood of injury may be acceptable. The application of these exemptions is typically reviewed on a reasonableness standard.

See Access Act, supra note 1, s 19, which states:

(1) Subject to subsection (2), the head of a government institution shall refuse to disclose any record requested under this Act that contains personal information as defined in section 3 of the Privacy Act.

(2) The head of a government institution may disclose any record requested under this Act that contains personal information if

(a) the individual to whom it relates consents to the disclosure;

(b) the information is publicly available; or

(c) the disclosure is in accordance with section 8 of the Privacy Act.

$14 \quad$ Ibid, s 21(1), which states:

The head of a government institution may refuse to disclose any record requested under this Act that contains

(a) advice or recommendations developed by or for a government institution or a minister of the Crown,

(b) an account of consultations or deliberations in which directors, officers or employees of a government institution, a minister of the Crown or the staff of a minister participate,

(c) positions or plans developed for the purpose of negotiations carried on or to be carried on by or on behalf of the Government of Canada and considerations relating thereto, or

(d) plans relating to the management of personnel or the administration of a government institution that have not yet been put into operation,

if the record came into existence less than twenty years prior to the request.

$15 \quad$ Ibid, s 15, which states, in part:

(1) The head of a government institution may refuse to disclose any record requested under this Act that contains information the disclosure of which could reasonably be expected to be injurious to the conduct of international affairs, the defence of Canada or any state allied or associated with Canada or the detection, prevention or suppression of subversive or hostile activities.

16 Bronskill, supra note 11 at para 68. It is possible, but unlikely, that this standard of review may be adjusted to a "reasonableness" standard in a future case through application of the Supreme Court's revised approach to standards of review. See Dunsmuir v New Brunswick, 2008 SCC 9, [2008] 1 SCR 190 [Dunsmuir]. 
Where the exemption is a mandatory exemption, the only task of the reviewing body is to find whether the decision-maker's determination of whether the information at issue fits within the exemption meets the appropriate standard. However, where the exemption relied upon is a discretionary exemption, the review proceeds to a second stage where the reviewing body determines whether the information should be disclosed notwithstanding the fact that it falls within the scope of the exemption. ${ }^{17}$ The second stage of review requires an assessment of whether the decision-maker has reasonably exercised the discretion granted to her under the statutory provision. This second stage also involves two steps: the first step is to determine whether the decision-maker turned her attention to the discretion; the second step is to determine whether the discretion was exercised reasonably. ${ }^{18}$

This multi-stage process has been articulated most clearly by courts in recent cases reviewing the reliance on discretionary exemptions in access regimes. This is not surprising given that courts have been considering the elements of judicial review with a renewed degree of care since the Supreme Court of Canada's decision in Dunsmuir, ${ }^{19}$ where it abandoned the patent unreasonable standard of review, causing a reevaluation of many aspects of the process of judicial review. ${ }^{20}$

More importantly, in recent cases, Canadian courts have actively challenged claims by government officials who purported to exercise discretionary exemptions to refuse disclosure of information under access to information legislation. In the course of this active review of discretionary decisions, the courts have more clearly articulated their expectations of how reliance on discretionary exemptions from disclosure may be justified.

\section{ONTARIo (PUBLIC SAFETY AND SECURITY) V. CRIMINAL LAWYERS' ASSOCIATION}

The Criminal Lawyers' Association decision released by the Supreme Court of Canada in 2010 is perhaps the Court's most important decision concerning access to information rights. In this case, the Court recognized that section 2(b) of the Charter protects a derivative right to access government information in certain circumstances. The case rightly garnered much attention because it was the first decision in which a majority of the Court recognized that there was constitutional protection for the right to access government information. However, while the Court recognized that section 2(b) protects a derivative right to access government information, it imposed strict preconditions that are necessary to trigger this protection. Indeed, the Court found that the facts were not sufficient to trigger the operation of section 2(b) in the Criminal Lawyers' Association case.

17 Justice Rothstein described this two stage process in Canada (Information Commissioner) $v$ Canada (Prime Minister) (1992), [1993] 1 FC 427, 57 FTR 180 at para 23, writing:

In the case of mandatory exemptions the only decision to be made is whether the record comes within the description that the Act requires be exempted from disclosure. In the case of discretionary exemptions such as that under section 14, two decisions are necessary: first, does the record come within the description that is contemplated by the statutory exemption invoked in a particular case; and second, if it does, should the record nevertheless be disclosed.

Attaran, supra note 10 at paras 14-18.

Dunsmuir, supra note 16.

For example, see the detailed discussion of the stages of review provided by Justice Nöel in Bronskill, supra note 11 at paras $62-82$. 
The case arose out of the trial of two men accused of committing an allegedly mob-related murder. The accused were convicted at their original trial but granted a second trial on the basis of fresh evidence. Prior to the second trial, the accused were granted a stay of all charges based on findings of abuse of process by both police and Crown counsel involved in the investigation and original trial. The judge who granted the stay, Justice Glithero, found "many instances of abusive conduct by state officials, involving deliberate non-disclosure, deliberate editing of useful information, negligent breach of the duty to maintain original evidence, improper cross-examination and jury addresses during the first trial."21

Based on Justice Glithero’s findings, the Ontario Provincial Police (OPP) conducted an investigation to determine whether criminal charges should be laid against the police officers or Crown attorneys involved in the case. The OPP released the findings of their investigation in a brief press release that announced that no charges would be filed as there was "no evidence that the officers attempted to obstruct justice by destroying or withholding a vital piece of evidence" and "no evidence that information withheld from defence was done deliberately and with the intent to obstruct justice.”22 There was no further explanation provided for the OPP's findings.

The Criminal Lawyers’ Association, which represents defence counsel in Ontario, made a formal request for access to three documents related to the OPP investigation. ${ }^{23}$ The Solicitor General (which later became the Ministry of Public Safety and Security) refused to disclose any information at all based on several provisions of the Ontario Freedom of Information and Protection of Privacy Act, including sections 14, 19, and 21. ${ }^{24}$ Section 14 provides decision-makers with discretion to refuse to disclose information related to law enforcement matters, while section 19 provides discretion to refuse to disclose information that is protected by solicitor-client privilege. Section 21 establishes a mandatory requirement that decision-makers refuse to disclose certain personal information of individuals. However, information that falls under the section 21 exemption may be disclosed pursuant to the section 23 public interest override, which provides that certain exemptions do not apply where a compelling public interest in disclosure of the information outweighs the purpose of the exemption.

The Criminal Lawyers' Association appealed the refusal to disclose any of the requested information to the office of the Ontario Information and Privacy Commissioner. In his decision, the Assistant Information and Privacy Commissioner (Assistant Commissioner) found that there was a compelling public interest in the disclosure of the information that would override the application of the section 21 personal information exemption. However, he also found that the section 14 and section 19 exemptions were properly relied upon and that the public interest override did not apply to those exemptions. As such, he upheld the refusal to disclose the requested information. ${ }^{25}$ The Criminal Lawyers' Association appealed the Assistant Commissioner's decision arguing, in part, that the fact that the public interest

As cited in Criminal Lawyers’ Association, supra note 2 at para 59.

As cited in ibid at para 11 .

The documents included a 318-page investigation report, a memorandum concerning the investigation and a letter concerning the investigation, ibid at para 12.

Freedom of Information and Protection of Privacy Act, RSO 1990, c F.31, ss 14, 19, 21 [Ontario FOIPPA].

Criminal Lawyers' Association, supra note 2 at para 15. 
override did not apply to either section 14 or section 21 infringed the right to freedom of expression protected by section 2(b) of the Charter. ${ }^{26}$

\section{A. The SuPREME CourT's Discussion OF AdMinistrative Discretion}

The case ultimately made its way to the Supreme Court of Canada. The Supreme Court's decision in the Criminal Lawyers' Association case is a fitting starting point for this discussion of judicial supervision of administrative discretion in access to information regimes because it provides an excellent example of how lawyers and legal scholars often focus on constitutional and statutory issues at the expense of administrative concerns. Thus, the various parties who argued the Criminal Lawyers' Association case focused their oral arguments almost exclusively on the issue of whether access to information should receive constitutional protection. Very little time was spent discussing whether the Assistant Information Commissioner had properly exercised his discretion under sections 14 and 19 of the $A c t .{ }^{27}$ Similarly, the academic and legal commentary that has discussed the Supreme Court's decision in the case has focused on the Court's approach to interpreting section 2(b) of the Charter, with very little time spent analyzing the Court's determination that the Assistant Commissioner had failed to properly exercise his discretion to order disclosure under the provisions in question. ${ }^{28}$

However, while the Court's determination that there may be some protection for access to information provided under section 2(b) of the Charter ultimately provided no relief for the applicants in this particular case, the Court ordered a reconsideration of the Assistant Commissioner's exercise of discretion pursuant to section 14 of the Ontario FOIPPA on administrative law grounds. The Court's decision in this case thus provides an important reminder of the key role of judicial review of administrative discretion in access regimes. In particular, Chief Justice McLachlin and Justice Abella, who wrote the Court's unanimous decision, emphasized that administrative law principles mandated that the discretion created by sections 14 and 19 must be exercised in accordance with the purposes of the legislative provisions creating the discretion. They stated:

A discretion conferred by statute must be exercised consistently with the purposes underlying its grant: Baker v. Canada (Minister of Citizenship and Immigration), [1999] 2 S.C.R. 817, at paras. 53, 56 and 65. It follows that to properly exercise this discretion, the head must weigh the considerations for and against disclosure, including the public interest in disclosure.

$27 \quad$ Ibid at para 6.

The Ontario Information and Privacy Commissioner has the power to order government officials to disclose documents. As such, in this case the court reviewed the reasonableness of the decision taken by the Assistant Commissioner as opposed to the reasonableness of the discretion exercised by the government decision-maker.

28 Gerald Chan, "Transparency Confined to the Courthouse: A Critical Analysis of Criminal Lawyers' Assn., C.B.C. and National Post”(2011) 54 Sup Ct L Rev (2d) 169; Ryder L Gilliland, "Supreme Court Recognizes (a Derivative) Right to Access Information” (2010) 51 Sup Ct L Rev (2d) 233; David Goodis \& Allison Knight, "Case Comment: Is There a Charter Right of Access to Government Information? The Supreme Court of Canada's Decision in Ontario (Public Safety and Security) $v$. Criminal Lawyers' Association” (2011) 29:2 NJCL 231; Patrick Monahan \& Chanakya Sethi, “Constitutional Cases 2010: An Overview” (2011) 54 Sup Ct L Rev (2d) 3. Daniel Guttman pays more attention to the administrative law aspects of the decision than other authors in "Criminal Lawyers' Assn. v. Ontario: A Limited Right to Government Information under Section 2(b) of the Charter” (2010) 51 Sup Ct L Rev (2d) 199. 
By way of example, we consider s. 14(1)(a) where a head "may refuse to disclose a record where the disclosure could reasonably be expected to ... interfere with a law enforcement matter". The main purpose of the exemption is clearly to protect the public interest in effective law enforcement. However, the need to consider other interests, public and private, is preserved by the word "may" which confers a discretion on the head to make the decision whether or not to disclose the information. ${ }^{29}$

The Chief Justice and Justice Abella outlined a number of factors that should be considered when exercising the discretion under section 14 of the Ontario FOIPPA, writing:

These determinations necessarily involve consideration of the public interest in open government, public debate and the proper functioning of government institutions. A finding at the first stage that disclosure may interfere with law enforcement is implicitly a finding that the public interest in law enforcement may trump public and private interests in disclosure. At the second stage, the head must weigh the public and private interests in disclosure and non-disclosure, and exercise his or her discretion accordingly. ${ }^{30}$

The decision thus clearly articulated the requirement that public officials exercising a statutory discretion to refuse disclosure of government information must consider the public and private interests in disclosing the information at issue in addition to the public and private interests in refusing to disclose the information when exercising their discretion.

Chief Justice McLachlin and Justice Abella concluded that the Assistant Commissioner failed to recognize that the Minister had a residual discretion to release the documents in question and thus also failed to consider whether the Minister properly exercised this discretion. They found that a review of the Minister's exercise of discretion under section 14 that considered the factors outlined in their reasons may well have resulted in a different conclusion than initially reached by the Assistant Commissioner. In particular, Chief Justice McLachlin and Justice Abella highlighted the fact that the Minister had refused to disclose a single page of the records requested and that he had not provided any reasons for his refusal to disclose the information requested. They stated: "[t]he absence of reasons and the failure of the Minister to order disclosure of any part of the voluminous documents sought at the very least raise concerns that should have been investigated by the Commissioner."31

Thus, in addition to highlighting the importance of considering the public interest in disclosing requested information when exercising discretion under access legislation, the decision in Criminal Lawyers' Association also suggested that courts will look more closely at both whether sufficient justification is provided to support decisions to refuse disclosure and the manner in which refusals are exercised. These trends are well illustrated by the decisions of the Federal Court and the Federal Court of Appeal discussed below. However, before moving to these decisions, it is worth noting that a review of recent decisions in Ontario and Alberta indicates that the guidelines articulated in the Supreme Court's Criminal Lawyers’ Association decision are being implemented by provincial access adjudicators.

Criminal Lawyers’ Association, supra note 2 at paras 46-47.

Ibid at para 48. Chief Justice McLachlin and Justice Abella found that the exercise of the discretion under section 19 of the Act was subject to similar restrictions. However, they noted that it would be extremely rare for the public interest in disclosure of a solicitor-client privilege to outweigh the purpose of the section 19 exemption (ibid at paras 53-54). Ibid at para 74 . 
An excellent example of the impact of the Criminal Lawyers' Association decision comes from a decision of an Alberta adjudicator considering a complaint under the Alberta Freedom of Information and Protection of Privacy Act. ${ }^{32}$ In Order F2012-08, adjudicator Teresa Cunningham provided her decision concerning a complaint by a number of funeral homes that Service Alberta had improperly refused to disclose documents they had requested. ${ }^{33}$ In particular, the funeral homes wished to gain access to documents held by the government department related to a particular investigation of the applicant funeral homes. Service Alberta relied upon several provisions of the Alberta FOIPPA to refuse to disclose a number of documents.

For the purpose of this article, the focus will be solely on the adjudicator's decision concerning section 24(1) of the Act. Section 24(1) of the Alberta FOIPPA provides the head of a public body with the discretion to refuse to disclose information that is part of the government decision-making process. ${ }^{34}$ In her reasons, adjudicator Cunningham noted that Service Alberta initially failed to provide any reasons for the exercise of its discretion not to disclose documents pursuant to section 24(1). As a result, in an Interim Order, adjudicator Cunningham had ordered Service Alberta to provide reasons for its decision to withhold documents pursuant to this provision. Indeed, adjudicator Cunningham had specifically referred Service Alberta to the decision in Criminal Lawyers' Association and had ordered the department to provide an affidavit from the individual responsible for deciding to withhold the information at issue. She also ordered the individual to answer specific questions in the affidavit including: "Were other relevant interests, such as the public interest in disclosure, considered when the decision was made to withhold these records? If so, how were these interests outweighed?"35

Adjudicator Cunningham found that the affidavit that was filed by Service Alberta in response to her Interim Order failed to answer whether other interests, including the public interest in disclosure, were considered by Service Alberta when it exercised its discretion. As a result, she found that she could not confirm that the decision-maker appropriately exercised its discretion under section 24(1)(a). ${ }^{36}$ Accordingly, the adjudicator ordered Service Alberta to reconsider its decision to withhold records under section 24(1)(a) of the Act and, when doing so, to "consider the relevant interests weighing in favor of disclosure in addition to those weighing against it, and all relevant circumstances.”37

Freedom of Information and Protection of Privacy Act, RSA 2000, c F-25 [Alberta FOIPPA]. Order F2012-08; Re Service Alberta Order F2012-08 of 27 April 2012, [2012] AIPCD no 10 (QL) [Re Service Alberta]. See also Re Alberta Health Services Order F20212-10 of 30 April 2012, [2012] AIPCD no 12 (QL) [Re Alberta Health Services]; and Re Alberta Innovates-Technology Futures Order F2021206 of 30 March 2012, [2012] AIPCD no 6 (QL) [Re Alberta Innovates-Technology Futures]. Section 24(1) states, in part:

(1) The head of a public body may refuse to disclose information to an applicant if the disclosure could reasonably be expected to reveal

(a) advice, proposals, recommendations, analyses or policy options developed by or for a public body or a member of the Executive Counsel,

(b) consultations or deliberations involving

(i) officers or employees of a public body,

(ii) a member of the Executive Council, or

(iii) the staff of a member of the Executive Council.

Re Service Alberta, supra note 33 at para 54.

Ibid at para 59.

Ibid at para 63. 
Adjudicator Cunningham explicitly acknowledged the direction provided by the Supreme Court's decision in Criminal Lawyers' Association, stating the following: Criminal Lawyers' Association "establishes that the Commissioner must test the exercise of discretion of the head of a public body when the head chooses to withhold information under a discretionary exception to disclosure." 38 While adjudicator Cunningham noted that the requirement to provide evidence that the discretion had been exercised to fulfill the goals of the statutory authority pre-dated Criminal Lawyers' Association, she acknowledged that the decision in Criminal Lawyers' Association established that "there is now increased emphasis as to whether interests in disclosing information have also been considered when exercising discretion."39

Adjudicator Cunningham also acknowledged that it would be possible to confirm the proper exercise of discretion after consideration of the public records and other submissions in some cases. ${ }^{40}$ Indeed, this seems to be the approach adopted in a number of recent decisions reached by adjudicators considering applications under the Ontario FOIPPA. One such case deals with a request for access to information concerning the post-termination payments made to the former manager of the City of Orillia. ${ }^{41}$ The City of Orillia refused to disclose information concerning how long the former manager would continue to collect a salary. It relied, in part, on section 6(1)(b) of the Ontario Municipal Freedom of Information and Protection of Privacy Act, which provides a discretion not to disclose information from a closed meeting. ${ }^{42}$ In an Interim Order, adjudicator Diane Smith ordered the City to reconsider the exercise of its discretion under section 6(1)(b). This process was described as follows:

In Interim Order MO-2768-I, I ordered the city to re-exercise its discretion with respect to the information at issue in Record 24. This order included the following analysis as to the considerations the city should take into account in the re-exercise of its discretion:

Based on my review of the city's representations, I find that it did not exercise its discretion in a proper manner. In applying section 6(1)(b), the city failed to take into account relevant factors. I find that the city did not adequately consider the transparency purpose of the Act or the fact that information about the payment of the affected person's salary after termination would be revealed by reason of the provisions of the PSSDA.

Ibid at para 62.

Ibid at para 48 .

Ibid at para 62. In other words, an affidavit explaining the decision-maker's exercise of discretion will not be necessary in all cases.

41 Re Orillia (City of) Final Order MO-2812-F of 13 November 2012, [2012] OIPC no 227 (QL) [Orillia]. The Municipal Freedom of Information and Protection of Privacy Act, RSO 1990, c M.56, section 6 states:

(1) A head may refuse to disclose a record,

(a) that contains a draft of a by-law or a draft of a private bill; or

(b) that reveals the substance of deliberations of a meeting of a council, board, commission or other body or a committee of one of them if a statute authorizes holding that meeting in the absence of the public.

(2) Despite subsection (1), a head shall not refuse under subsection (1) to disclose a record if,

(a) in the case of a record under clause (1) (a), the draft has been considered in a meeting open to the public;

(b) in the case of a record under clause (1) (b), the subject-matter of the deliberations has been considered in a meeting open to the public; or

(c) the record is more than twenty years old. 
[T] he city has failed to take into account ... the public interest in information relating to the amount paid under a settlement agreement, and the fact that, in the absence of a section 6(1)(b) exemption claim, a significant amount of information about the termination of employment with public bodies is often ordered disclosed. ${ }^{43}$

Pursuant to the Interim Order, the City reconsidered the exercise of its discretion and again determined that it should withhold the information. The City argued that it considered the transparency interest in publishing the requested information but concluded that it was bound by a confidentiality agreement to refuse to disclose the information. ${ }^{44}$ Adjudicator Smith specifically referred to the process for reviewing discretionary decisions set out in the Criminal Lawyers' Association decision and concluded that, based on the City's representations, the City had taken into account the relevant considerations in exercising its discretion. ${ }^{45}$

The Interim Order issued in the Orillia decision provides an excellent example of the way in which the failure to consider the public interest in disclosure may trigger the requirement to reconsider the exercise of a discretionary exemption under access legislation. In turn, the Final Order issued in this case demonstrates how evidence of the consideration of all relevant factors provides a justification for the exercise of a discretion not to disclose information pursuant to such discretionary exemptions.

The influence of the Criminal Lawyers' Association decision was even more explicitly noted by adjudicator Colin Bhattacharjee, in Order PO-3117 relating to an application under the Ontario FOIPPA for access to records held by the Ministry of Community Safety and Correctional Services. ${ }^{46}$ In this case, the applicant was seeking records relating to her son's murder in a federal correctional facility. The Ministry refused to disclose most of the records that were relevant to the request, relying in part on section 14(1)(b) of the Ontario FOIPPA. In particular, the Ministry exercised its discretion to refuse to disclose the records based on its assessment that disclosure of the documents could reasonably be expected to interfere with the ongoing investigation of the murder by the Ontario Provincial Police.

In his decision, adjudicator Bhattacharjee referred to the test for exercise of discretion set out in Criminal Lawyers' Association and concluded that the Ministry had satisfied the test. In particular, adjudicator Bhattacharjee found that:

I am satisfied that after the ministry concluded that disclosing the records could reasonably be expected to interfere with the OPP's murder investigation under section 14(1)(b), it weighed the public and private interests in disclosure and non-disclosure, and exercised its discretion to withhold the records. In particular, it took into account the fact that the appellant received a large number of records during the Coroner's

Re Ontario (Ministry of Community Safety and Correctional Services) ORDER PO-3117 of 10 October 2012, [2012] OIPC no 199 (QL) [Re Ontario]. 
inquest and concluded that the need to protect the integrity of the OPP's murder investigation trumps the public and private interests in further disclosure.

I am not persuaded that the ministry failed to take relevant factors into account or that it considered irrelevant factors in withholding the records. I find, therefore, that it exercised its discretion under section 14(1)(b) and did so in a proper manner. ${ }^{47}$

Adjudicator Bhattacharjee's reasons demonstrate again that the exercise of discretion may be justified provided that there is sufficient evidence that the decision-maker has considered both the public and private interests in disclosure and non-disclosure.

These decisions from Alberta and Ontario access to information adjudicators provide evidence that the Supreme Court of Canada's decision in the Criminal Lawyers' Association case has provided an important guide for front-line officials responsible for supervising the exercise of administrative discretion under access to information regimes. While the requirement that discretionary powers should be exercised pursuant to the goals of the statutory provisions that establish the discretion is a long-standing principle of administrative law, the Criminal Lawyers' Association decision emphasized that this principle requires government decision-makers to consider both the public interest in refusing disclosure and the public interest in disclosure before deciding to refuse disclosure under discretionary exemptions.

The decision also provided a reminder that decision-makers cannot simply exercise their discretion to refuse disclosure of information without providing reasons in support of their decisions or without consideration of severing information that can be disclosed. The insistence on providing reasons is in keeping with the Supreme Court's recognition of the importance of reasons in administrative decisions in Baker v. Canada (Minister of Citizenship and Immigration). ${ }^{48}$ As noted by David Dyzenhaus, among others, the provision of reasons is a key component of a democratic system of government where decisions are "justified" rather than simply asserted. ${ }^{49}$ It is particularly apt that government officials should engage in the "justificatory exercise of reason-giving" 50 when they take procedural decisions to limit access to information. After all, access to government information is key to the citizens' ability to assess the reasons provided by the government to justify its substantive decisions. $^{51}$

$47 \quad$ Ibid at paras 131-32 [emphasis added].

[1999] 2 SCR 817.

David Dyzenhaus, “Constituting the Rule of Law: Fundamental Values in Administrative Law” (2002) 27:2 Queen's LJ 445 at 501-502; David Dyzenhaus, “Baker: The Unity of Public Law?” in David Dyzenhaus, ed, The Unity of Public Law (Portland: Hart Publishing, 2004) at 1, 7.

Ibid at 501-502.

For discussion of the importance of access to government information to democratic accountability see Alasdair Roberts, "Structural Pluralism and the Right to Information" (2001) 51:3 UTLJ 243; Gregory Tardi, The Law of Democratic Governing: Principles, vol 1 (Toronto: Thomson Carswell, 2004) at 38; Craig Forcese, “Clouding Accountability: Canada’s Government Secrecy and National Security Law “Complex”” (2005) 36:1 Ottawa L Rev 49 at 53-56; Vincent Kazmierski, “Something to Talk About: Is There a Charter Right to Access Government Information?” (2008) 31:2 Dal LJ 351. 
Indeed, it is important to recall that in Criminal Lawyers' Association, the Supreme Court underlined the fundamental importance of access to government information in the democratic process by recognizing that access may, in specific circumstances, receive constitutional protection as a derivative right under section 2(b) of the Charter. Thus, while the Court's treatment of the exercise of administrative discretion exercised by the Assistant Information Commissioner in that case was rooted in administrative law principles as opposed to Charter analysis, it is likely that the judicial acknowledgement of the link between access to information and freedom of expression will provide added incentive, although not necessarily added authority, to scrutinize the exercise of discretion to refuse disclosure of information. ${ }^{52}$

Two recent decisions of the Federal Court have gone even further than the Criminal Lawyers' Association decision in articulating the standards to be met by government officials who purport to rely on discretionary exemptions to refuse disclosure of government information.

\section{AtTARAN V. CANADA (Minister of Foreign AFFAiRs)}

Perhaps not surprisingly, the decisions in which courts have articulated even more robust approaches to the review of administrative discretion deal with claims of exemptions based on national security. Such claims are a key area of concern as they provide perhaps the greatest potential for expansive application of exemptions by government-officials combined with excessive deference by those responsible for supervising the exercise of discretion. The potential problems posed by exemptions based on national-security concerns are heightened by the fact that information applicants are often prohibited from reviewing both the records at issue and the evidence offered in support of the decision to refuse disclosure. In short, applicants are kept in the dark about both the information requested and the reasons that the information will not be disclosed. The two cases discussed below are examples of ways in which judicial review of the exercise of discretion may cast light on the rationales for refusing disclosure and, in so doing, facilitate access to the information itself.

The first case of interest is the decision of the Federal Court of Appeal in Attaran $v$. Canada (Minister of Foreign Affairs). ${ }^{53}$ The Attaran case was prompted by a law professor's request for copies of the Department of Foreign Affairs and International Trade's (DFAIT) annual human rights reports for Afghanistan from 2001 to 2006. This request was part of Professor Attaran's attempts to determine whether Canadian authorities authorized the transfer of military prisoners to Afghan authorities despite knowledge that prisoners were (or may have been) subject to torture when detained by Afghan authorities. ${ }^{54}$

52 The Supreme Court's reasons in Criminal Lawyers' Association suggest that administrative law principles are sufficient to ground active review of administrative discretion to refuse disclosure of government information. If courts seek to also rely on Charter values to ground such review, they will need to take account of the Supreme Court's guidelines for balancing between administrative law principles and Charter values as expressed in Doré v Barreau du Québec, 2012 SCC 12, [2012] 1 SCR 395.

53 Attaran, supra note 10.

Ibid at paras 1-6. 
The request for the reports was ineffective; DFAIT indicated that no report existed for 2001 and it provided Professor Attaran heavily redacted reports for the other years. Professor Attaran complained to the Information Commissioner of Canada concerning the limited disclosure. While Professor Attaran was later provided additional information by DFAIT, he ultimately sought judicial review of DFAIT's refusal to disclose all the information he sought. Although he ordered one excerpt of the record to be disclosed, the application judge upheld DFAIT's refusal to disclose the rest of the records as a reasonable exercise of its discretion to refuse disclosure of information that "could reasonably be expected to be injurious to the conduct of [Canada's] international affairs" under section 15 of the Access Act. $^{55}$

Professor Attaran appealed to the Federal Court of Appeal. He did not challenge whether the information at issue fell under the ambit of section 15 of the Access Act, but rather challenged whether DFAIT had reasonably exercised its discretion to refuse disclosure of the information he sought, in particular, information relating to torture of prisoners detained by Afghan authorities. ${ }^{56}$ Justice Dawson, writing for the Court, overturned the decision of the application judge and found that the "head" of DFAIT had failed to properly exercise the discretion granted under section 15(1) of the Act. The Court returned the matter to DFAIT for reconsideration with proper exercise of its discretion. ${ }^{57}$

Justice Dawson's decision touched on a number of important aspects of judicial review of discretionary decisions under the federal Access Act. First, Justice Dawson clarified that applicants who were not permitted to review the information being sought and who could not access the evidence offered to support the refusal to disclose information should not bear the burden of proving that the government official had failed to exercise her discretion reasonably. Thus, while in many cases the burden of proof shifts from the government to the applicant to demonstrate that the government official exercised her discretion unreasonably once the government demonstrates that the information falls within the exclusion set out in the statute, this will not be true in all cases. In particular, the Federal Court of Appeal found that the government had the burden to prove that its official exercised her discretion reasonably in cases where the applicant cannot access the record that demonstrates how the discretion was exercised. Justice Dawson explained:

However, the appellant is unaware of the precise content of the unredacted record, unaware of the ex parte evidence filed by the respondent and unaware of the ex parte submissions made by the respondent in the in camera hearing. The public affidavits were silent on what if any factors were considered in the exercise of the discretion. The Federal Court provided no explanation for its conclusion that the respondent had considered the exercise of discretion. The appellant argues there is no evidence in the public record that consideration was given to the exercise of discretion. He has no means of verifying from the ex parte record if the discretion was exercised.

In my view, the circumstances in this case are analogous to those before this Court in Ruby. The appellant cannot be required in this case to bear the burden of establishing on a confidential record he cannot access

Ibid at para 5.

Ibid at paras 2-3.

Ibid at para 4. 
that the respondent failed to give consideration to the exercise of discretion. The burden of proof is on the respondent to establish that the discretion was exercised in a reasonable manner. ${ }^{58}$

Justice Dawson found that there was no evidence in either the ex parte record or the public record that "expressly demonstrates that the decision-maker considered the existence of her discretion."59 Justice Dawson acknowledged that this absence of evidence would not be determinative of the issue. However, she also noted that bald statements that the discretion had been exercised could also not determine the issue.

\begin{abstract}
Conversely, just as the absence of express evidence about the exercise of discretion is not determinative, the existence of a statement in a record that a discretion was exercised will not necessarily be determinative. To find such a statement to be conclusive of the inquiry would be to elevate form over substance, and encourage the recital of boilerplate statements in the record of the decision-maker. In every case involving the discretionary aspect of section 15 of the Act, the reviewing court must examine the totality of the evidence to determine whether it is satisfied, on a balance of probabilities, that the decision-maker understood that there was a discretion to disclose and then exercised that discretion. ${ }^{60}$
\end{abstract}

Justice Dawson also went on to note that the prior public disclosure of information suggested that the decision-maker should exercise her discretion to disclose the information to the applicant. While the prior public disclosure of the information would not guarantee disclosure to the applicant in all cases, the prior public disclosure should certainly be considered when weighing whether the discretion to disclose should be exercised. ${ }^{61}$

In summary, the Court of Appeal's decision in Attaran underlined that there must be sufficient evidence to support the contention that decision-makers have reasonably exercised their discretion not to disclose information pursuant to discretionary exemptions under the Access Act. Of course, the nature of that evidence and the burden of proof may shift depending on the nature of the information request. In every case, the determination of whether the discretion has been exercised properly should be based on the totality of the evidence.

Perhaps more importantly, Attaran clarified that the government will bear the burden of proof in cases where the applicant has no access to the records at issue or to the evidence that supports the exercise of the discretion. In addition, bald statements that the discretion has been exercised will not be sufficient to approve the exercise of the discretion. Similarly, the failure of government officials to consider whether the information at issue has been already

\footnotetext{
Ibid at paras 26-27.

Ibid at para 35.

Ibid at para 36 [emphasis added].

Ibid at para 41. In this paragraph, Justice Dawson wrote:

There is no indication that the respondent considered at any time after the initial release of information to the appellant whether the prior public disclosure of redacted information was a relevant factor when considering the discretion to disclose documents that otherwise fell within the scope of subsection 15(1). While this may not be true in all cases, the prior public disclosure of information provided an incentive for the exercise of discretion to release the information to the appellant. This is particularly true in the present circumstances, where a DFAIT employee had publicly confirmed the phrase was in the report. The prior public disclosure might not have been sufficient to lead the respondent to release the information to the appellant. However, if the respondent understood that such discretion existed, one would expect to find something in the record that manifested consideration of the discretion. [Emphasis added.]
} 
released publicly may be taken as an indication that the discretion has not been reasonably exercised.

\section{BRonskill V. CANAdA (MINISTER of CANAdian NATIONAL HERITAGE)}

Another recent case that illustrates the robust judicial approach to reviewing discretionary decisions in access cases is the decision of Justice Nöel of the Federal Court in Bronskill v. Canada (Minister of Canadian National Heritage). ${ }^{62}$ The Bronskill case arose out of a request for access to the Royal Canadian Mounted Police (RCMP) dossier on Tommy Douglas, the former premier of Saskatchewan. The applicant, Jim Bronskill, is a journalist who wished to review the dossier as part of his research for possible newspaper stories he was preparing in relation to the twentieth anniversary of Douglas's death. He applied to Library and Archives Canada (LAC) for a copy of the RCMP's security service files on Douglas. $^{63}$ LAC consulted with the Canadian Security Intelligence Service (CSIS) concerning the nature of the files and the applicability of exemptions under the federal Access Act. LAC ultimately relied on section 15 of the Access Act to refuse disclosure of parts of the RCMP files. ${ }^{64}$

Bronskill complained to the Information Commissioner of Canada concerning the exemptions claimed by LAC, but the Information Commissioner concluded that LAC's reliance on section 15 to refuse disclosure was justified. Bronskill brought an application for review of LAC's refusal to disclose the records before the Federal Court. ${ }^{65}$ It is important to note at the outset that Justice Nöel's decision was heavily informed by the dual mandate of LAC to acquire and preserve the documentary heritage of Canada while also facilitating access to that heritage and making it known. This mandate reinforces the mandate of the

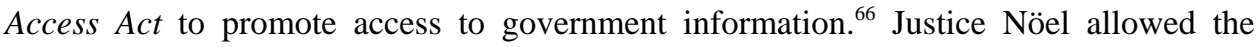
application and sent the matter for redetermination by LAC. He also ordered LAC to justify in writing whether it had more information concerning Douglas than it had already disclosed. ${ }^{67}$

\section{A. STANDARD OF REVIEW}

Justice Nöel began by considering the issue of the proper standard of review to apply to the decisions in the case. He noted that this inquiry must consider the precise nature of the exemption relied upon by the decision-makers. In this case, the exemption relied upon was

Bronskill, supra note 11.

Ibid at para 29.

Ibid at paras 36-39.

Ibid at paras 37-39.

Justice Nöel described the importance of the mandate of LAC as follows:

Considering the broad definitions of "government or ministerial record" and "government institution" found within the Library and Archives of Canada Act, it can be said that the ultimate approval of destruction and retention of documentation is an integral part of LAC's mandate. Evidently, Parliament considers access to information in Canada and document retention as essential components of citizens' right to government information.

Ibid at para 17. Later, Justice Nöel noted that "the dynamic mandate and purpose of LAC, including the intrinsic value of documentary archives and access thereof, must be considered by any decision-maker when considering ATI requests, as these fully complement the objectives and spirit of the Act itself." Ibid at para 25. 
discretionary and injury-based as opposed to class-based. Justice Nöel noted that the determination of whether a class-based exemption applies in a case may be reviewed according to a correctness standard. As noted earlier, information either fits into the class or it does not. However, decisions that involve an assessment of possible injury are not subject to the same categorical assessment and should be reviewed according to the reasonableness standard. Similarly, review of the exercise of discretion by decision-makers should be subject to the reasonableness standard. ${ }^{68}$

Justice Nöel also considered how much deference should be accorded to government officials acting as decision-makers under the federal Access Act. The federal Access Act is notably different than provincial access legislation because the federal one does not provide the Information Commissioner of Canada with the power to order production of documents. As a result, judicial review under the federal Access Act focuses on the decision to refuse disclosure of information taken by the government decision-maker rather than the decision of the Information Commissioner concerning whether the information should be disclosed. This means that reviewing courts must take into account the fact that the government decision-makers may have a vested interest in determining whether information fits within particular exemptions or whether the discretion to release information should be exercised. ${ }^{69}$ As Justice Nöel noted, "institutions responding to access to information requests may tend to apply exemptions liberally so as to limit disclosure and scrutiny of their organization.,"70

Justice Nöel determined that the deference owed to the expertise of the decision-makers under section 15 of the Access Act was at the lower end of the spectrum. He based this finding on a number of factors, including the fact that the decision-makers may interpret exceptions liberally, the fact that interpretation of the Act is a legal question, and the fact that judicial review under the Act involves a de novo review of the records in order to determine whether the exemptions can be reasonably applied to the information at issue. ${ }^{71}$ In particular, Justice Nöel stated:

\footnotetext{
However, the Act's objectives and their interpretation by the courts is such that this discretion is on the lower end of the spectrum, and that the Court is given ample jurisdiction and powers to review the exemptions claimed, as well as the exercise of discretion. This conclusion is necessary for the Act to be given its full meaning and breadth. As the Federal Court of Appeal noted in Telezone "if the Court were to confine its duty under section 41 to review ministerial refusals of access requests by deferring to ministerial interpretations and applications of the Act, it would, in effect, be putting the fox in charge of guarding the henhouse.”... Therefore, some deference has to be given, but not to the point of neutralizing the role of the judiciary as provided for by the legislation. $^{72}$
}

Thus, while discretionary decisions to refuse disclosure must only meet a standard of reasonableness, Justice Nöel's reasons suggest that courts must still play an active role in probing the explanations provided to support such refusals. 


\section{B. THE EVIDENCE REQUIREMENT}

The overriding issue in the Bronskill case concerned whether LAC had provided sufficient evidence to support its claims that, first, the documents it refused to disclose fell under the ambit of section 15 of the Act and, second, that it had properly exercised its discretion under section 15 when it decided not to disclose the information at issue. Due to the sensitive nature of the files at issue, the application involved both an in camera hearing and a public hearing. ${ }^{73}$

The appellant claimed that LAC had failed to provide sufficient evidence to support its claims either in the in camera hearings or in the public hearing. Justice Nöel agreed. He found that the affidavits filed by the respondents provided only general class-based arguments supporting the refusal to disclose information and failed to "indicate the specific relation between disclosure of precise documents and the alleged injury." " Justice Nöel also found an absence of evidence in support of the exercise of discretion: "In respect to discretion, no information was submitted as to whether historical interests were balanced with national security concerns."75

\section{DETERMINATION OF WHETHER THE INFORMATION FITS WITHIN THE EXEMPTION}

Justice Nöel considered the arguments advanced by LAC in favour of each type of information that LAC sought to exempt from disclosure. He began by listing "general considerations." These included that the respondent bore the burden of establishing that the information fits within the exemption relied upon. Justice Nöel also considered the precise standard that must be met in order to establish that the information fit within the section 15 exemption. ${ }^{76}$ He concluded that the respondent must demonstrate that disclosure of the documents would raise "a reasonable expectation of probable harm" and that this task

LAC relied upon affidavits from three officials, including the Access to Information and Privacy Coordinator for CSIS (Nicole Jalbert), the Acting Director of the Access to Information, Privacy and Personnel Records Division of LAC (Bill Wood) and an articling student from the Department of Justice (Heather Squires) (ibid at paras 115, 118-19).

$74 \quad$ Ibid at para 116. Justice Nöel referred specifically to the affidavit of Ms Jalbert, but none of the other affidavits provided information concerning the "specific relation between disclosure of precise documents and the alleged information' either.” Ibid.

75 Ibid. The fact that the respondents provided only general evidence to support their claim that the excluded documents fit within section 15 of the Access Act led to the following expression of frustration from Justice Nöel:

Such is the Respondent's evidence. In all candour, the Court can state that the enterprise of reviewing the documentation consisted mainly of deductions and reading into the Respondent's general submissions and evidence. Courts have consistently recognized the requirements of "specific and detailed" evidence as the Respondent's burden in an ATI case. The large volume of documents, spanning over forty years of RCMP activities, probably did not lend itself to the timeconsuming enterprise of specifically and precisely detailing the alleged injury, but surely it is not for the Court to endeavor such an enterprise without more evidence from the Respondent. Considering the important interests at play when dealing with national security information, it was clear that the application could not be granted on the sole basis of the Respondent's incapacity to meet evidentiary requirements. However, it should be said that the Court's resources were considerably taxed during the course of the review of the documentation, as the evidence did not deal specifically with the documentation. Surely, the onus should not be on the Court to infer probable injury from over 1000 pages of documentation. More should be done on the Respondent's part to provide more specific information, especially as a result of the second review of the documentation. 
involved a "heavy onus.",77 Justice Nöel explained this onus by citing Justice Rothstein’s decision in Canada (Information Commissioner) v. Canada (Prime Minister), writing:

\begin{abstract}
Justice Rothstein, as he then was, articulated the standards which heads of government institutions refusing disclosure must meet in the seminal Canada (Information Commissioner) $v$ Canada (Prime Minister). Noting that the Court can only act upon the evidence before it, Justice Rothstein stated that the party seeking to maintain confidentiality must demonstrate its case "clearly and directly" and that a "general approach to justifying confidentiality is not envisaged" (Canada (Information Commissioner) v Canada (Prime Minister). It has also been stated that a clear and direct linkage is required between the evidence adduced and the alleged injury, the latter which must also not be speculative.
\end{abstract}

The Court can do no better than to cite Justice Rothstein again in the case of Canada (Information Commissioner) $v$ Canada (Prime Minister), above, at para 122, when it was stated in all clarity that:

Descriptions of possible harm, even in substantial detail, are insufficient in themselves. At the least, there must be a clear and direct linkage between the disclosure of specific information and the harm alleged.... The more specific and substantiated the evidence, the stronger the case for confidentiality. The more general the evidence, the more difficult it would be for a court to be satisfied as to the linkage between disclosure of particular documents and the harm alleged. ${ }^{78}$

Justice Nöel also insisted that the respondent must apply a consistent approach to decisions concerning disclosure of a multitude of documents and sources of information. ${ }^{79}$ He concluded that LAC officials had failed to apply a consistent approach to determine which information should be released and which information should be disclosed. ${ }^{80}$

Justice Nöel's decision rebuffed LAC's claims that a number of different categories of documents would meet the threshold that their release would raise a "reasonable expectation of probable harm" triggering the section 15 discretionary exemption.$^{81}$ In recognition of the sensitive nature of intelligence gathering operations, Justice Nöel accepted that documents would likely meet this threshold if they identified current operational interests; they

Justice Nöel wrote:

The standard of proof to be met by the Respondent, as the party resisting disclosure, requires that a "reasonable expectation of probable harm" is to be shown (Canada Packers v Canada (Minister of Agriculture), above; Canada (Information Commissioner) v Canada (Prime Minister), above). This burden of proof has been interpreted as a "heavy onus" (Canada (Information Commissioner) $v$ Canada (Prime Minister), above, at para 113; see also Sherman v. Canada (Minister of National Revenue), 2004 FC 1423; Rubin v Canada (Mortgage and Housing Corp.), [1989] 1 FC 265 (FCA)).

Ibid at para 125 [emphasis added]. It is important to note that the "heavy onus" identified by Justice Rothstein and endorsed by Justice Nöel does not increase the burden of proof beyond the civil burden of a balance of probabilities. (ibid, citing Attaran, supra note 10 at para 200).

Ibid at paras 126-27 [citations omitted] [emphasis added]. Justice Nöel went on (at para 129) to repeat a list of ten factors or guidelines that Justice Rothstein noted should be considered when determining whether reasonable expectations of probable harm have been established.

Ibid at para 133 [emphasis added], he stated:

The assessment of the reasonable expectation of probable harm is one that must be consistent. It would be highly illogical, and run counter to the Act, if the head of a government institution would apply inconsistent standards between different documents, more so if the inconsistencies would be in the very same ATI request. Where the decision-maker must make a determination of the injury caused by disclosure, inconsistent redactions and assessments of the injury resulting from disclosure may constitute grounds for additional disclosure ordered by the Court. 
identified human sources; if the information was obtained from particular types of technical sources (not transitory in nature); and the information included the names of RCMP officers who were involved in covert operations as infiltrators or sources. ${ }^{82}$ However, he rejected LAC's initial attempt to apply section 15 to exclude disclosure of information concerning the past targets of investigations by the RCMP intelligence services. ${ }^{83}$

Justice Nöel was particularly upset that LAC initially refused to disclose information about RCMP investigations that had already been denounced by the McDonald Commission, which had been established in 1977 to investigate illegal activities conducted by the RCMP. He wrote: "Basically, a Royal Commission denounced some of the RCMP's activities. Today, under the Act, access to the first-hand source of information about the scope and purpose of these activities is refused. This is unacceptable." ${ }^{44}$ Justice Nöel went on to emphasize the critical importance of allowing access to documents that shed light on the historical malfeasance of state agents. He wrote:

Thus, there is no reasonable ground for injury preventing the release of these documents. History and Canadian democracy require that historical facts, like the monitoring of legitimate political activities, be known. Refusing disclosure under the Act of these historical events is unacceptable in most circumstances, more so when this is already made public through a Royal Commission initiated for the very purpose of investigating these activities. ${ }^{85}$

Justice Nöel also rejected LAC’s attempts to justify the exclusion of documents where Douglas was only mentioned in passing, or incidentally, on the basis that it would be unfair to Douglas to release the documents. Justice Nöel rejected this argument, noting that the assessment of Douglas's person and career would be made by Canadians and by "History" as a result of study and debate. He further noted that nothing in the Act permitted government officials to exclude documents based on an internal assessment of their "relevance." 86 Justice Nöel ordered the reconsideration of the documents that LAC had excluded from disclosure in these problematic categories. ${ }^{87}$

Ibid at paras 123-77.

It is worth noting that Justice Nöel acknowledged that LAC's second review of the documents adopted a more reasonable approach when dealing with information concerning investigation targets of a "transitory nature" (ibid at 157-58).

Ibid at para 164.

Ibid at para 168 .

Ibid at paras 178-81.

Ibid at 225. Interestingly, Justice Nöel's decision was varied on appeal before the Federal Court of Appeal. In extremely brief reasons, Justice Nadon, writing for the Federal Court of Appeal, noted that, in light of concessions made by counsel for LAC at the appeal hearing, the Court would not interfere with the judgment rendered by Justice Nöel other than to vary two aspects of the judgment. One of these variations was to strike the words "with specific guidance to consider these reasons, their spirit as well as the examples found in the Annex" from Justice Nöel's order for LAC to reconsider its original decision. It is also important to note that the Court explicitly stated that, given it was not necessary to review Justice Nöel's reasons, "we do not wish to be taken as to having endorsed him" (Bronskill v Canada (Minister of Canadian Heritage), 2012 FCA 250, 356 DLR (4th) 192 at paras 1-2). Given the length and complexity of Justice Nöel's reasons, it is not surprising that the Court of Appeal would not wish to endorse the entire set of reasons in its own very brief judgment. However, for the same reason, it is difficult to speculate whether the Court had specific reservations concerning Justice Nöel's reasons. 


\section{REVIEWING THE EXERCISE OF DISCRETION}

Justice Nöel then went on to consider whether LAC had reasonably exercised its discretion under section 15. Justice Nöel confirmed that the burden of demonstrating that the exercise of discretion was reasonable may shift depending on the case. He noted that applicants cannot be expected to bear the burden when they do not have access to the information requested or to the record supporting its confidentiality. As a result, Justice Nöel found that the respondent government department in Bronskill, like the respondent in the Attaran case, bore the burden to demonstrate that it exercised its discretion not to disclose the information at issue in a reasonable manner. ${ }^{88}$

As noted above, Justice Nöel found that there was no evidence that LAC had exercised its discretion under section 15 during its first review of the documents. However, LAC submitted that the release of further documents after the second review of the documents was in fact the result of the exercise of its discretion. ${ }^{89}$ Justice Nöel did not accept this bald statement, noting that "[n]o specific and detailed evidence was given in regards to this

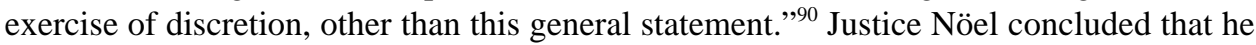
was not satisfied, on the balance of probability, that LAC exercised its discretion reasonably. Thus, while Justice Nöel was certain that LAC was aware of the discretion under section 15 during the second review of documents (for the simple reason that he identified the discretion in the in camera hearing that preceded the review), he found that he could not infer that the discretion "was used reasonably, if at all."

Justice Nöel identified the following important factors to be considered in the exercise of discretion under section 15 of the Access Act in this case. He reiterated that the evidence supporting refusal to disclose must be "specific and detailed" and that the "prejudice alleged in disclosure must not be abstract or speculative." 92 He also underlined that the residual discretion exists in order to permit disclosure of information even if its disclosure raises a reasonable expectation of probable harm. According to Justice Nöel, "[t]he conferral of discretion by the Act is the embodiment of a clear legislative intent that some information

$88 \quad$ Bronskill, supra note 11 at para 124.

89 The Bronskill case included two stages of disclosure as the respondent undertook to engage in a second review of the information at issue after the in camera hearing was held. As a result of this second review, LAC disclosed further information, but continued to refuse to disclose substantial amounts of information on the basis of the section 15 discretionary exemption. Justice Nöel's decision ultimately focused on the information that was not disclosed after the second review. However, he was careful to point out that the first review conducted by LAC failed to meet the standards imposed by the Access Act. Justice Nöel stated:

For the purpose of clarity, and before the second review of the documentation will be further discussed, it is appropriate for the Court to state that the information that was first withheld from the Applicant was clearly done in a manner that runs counter to the Act's principles, as well as the mandate of LAC. Furthermore, it can be said that LAC failed to exercise its residual discretion, once the documents had been seen to be covered by the section 15 exemption. The finding that the release of several documents would imply "reasonable expectation of probable harm" was flawed for a considerable portion of the documentation, as the subsequent disclosure resulting from this proceeding has shown. There was simply no exercise of the residual discretion for release, which is necessary for the realization of the Act's purpose, as well as LAC's mandate to preserve and diffuse Canada's history.

Ibid at para 136.

Ibid at para 199.

Ibid at para 204.

Ibid at para 211. 
may well be disclosed despite an alleged injury."93 Indeed, Justice Nöel noted that there should be a "presumption in favour of disclosure when exercising discretion."94

Not surprisingly, Justice Nöel also discussed the issue of whether there was an obligation to consider the public interest in disclosure of the requested information. He found that the principles and objectives of the Access Act and the Library and Archives of Canada Act ${ }^{95}$ (which favour disclosure) must be considered. ${ }^{96}$ While noting that there is no 'direct' or explicit requirement to consider public interest in disclosure of information under section 15, Justice Nöel applied the Supreme Court's approach in Criminal Lawyers' Association to recognize a duty for the decision-maker to consider the public interest in disclosure:

\begin{abstract}
However, given the principles of the Act and the qualification of LAC's mandate of preserving and facilitating access to information as being contributory to our democratic life, there is an arguable implicit public interest in access to information requests. While not directly at play and not as a stand-alone argument to counter necessary exemptions, the public's right to know is always at the heart of any ATI request, not least because of the Act's quasi-constitutional nature. Further to this argument, the Act itself cannot be used to hide embarrassments or illegal acts (see para 131 of these reasons), thereby recognizing an inherent public interest in the application of the Act.
\end{abstract}

In its qualification of the residual discretion for disclosure of exempt information, the Supreme Court noted that the decision-maker "must go on to ask whether, having regard to all relevant interests, including the public interest in disclosure, disclosure should be made” (Ontario (Public Safety and Security) v Criminal Lawyers' Association, at para 66). ${ }^{97}$

Justice Nöel also found that the passage of time should be considered both when conducting the injury analysis and when exercising the discretion to disclose. For example, the passage of time since the creation of the record may reduce the likelihood of harm from disclosure of the information. ${ }^{98}$ Similarly, Justice Nöel found that, in some cases, prior public disclosure of the information may significantly reduce the possible harm from further disclosure of the information and thus weigh in favour of releasing the information. ${ }^{99}$

In summary, the decision in Bronskill highlighted the fact that the exercise of discretion by government decision-makers to refuse disclosure for injury-based discretionary exemptions must be justified, not simply asserted. The decision identified a number of important factors to be considered when reviewing such exercises of discretion. Decisionmakers should provide clear and precise evidence that the exemption can be relied upon by establishing that a reasonable expectation of injury arising from disclosure exists. They should also provide clear and precise evidence to support their exercise of discretion.

\footnotetext{
$93 \quad$ Ibid at para 211.

Ibid at para 210 .

Library and Archives of Canada Act, SC 2004, c 11.

Bronskill, supra note 11 at para 214.

Ibid at paras 215-16.

Justice Nöel stated: “As such, if injury is present, yet at a lower end of the spectrum, the passage of time may be an important factor. This is the case because as the times change, so do the bases of 'reasonable expectation of probable harm', save for the protection of human sources, current operational interests and similar issues" (ibid at para 218). 
However, this evidence need not always take the form of affidavit evidence articulating the rationale for the exercise of discretion.

While the exercise of discretion is subject to a standard of reasonableness, this standard is not one that includes excessive deference to the decision-maker. In addition, in cases where the applicant has no access to the information at issue or the evidence advanced to support the refusal to disclose, the burden may shift to the government to justify the reasonableness of the exercise of its discretion. Ultimately, the exercise of discretion must include consideration of the public interest in disclosing the information in addition to the public interest in refusing disclosure. Indeed, Justice Nöel suggested that, in light of the purposes of the Act, there should be a presumption of disclosure when exercising discretion under it.

\section{ASSESSING THE IMPACT OF \\ Criminal LAWYERS' ASSOCIATION, ATTARAN, AND BRONSKILL}

The lasting impact of the three judicial decisions discussed in this article remains to be determined. The most immediate consideration is the impact of the decisions on the oversight of administrative discretion exercised by information commissioners across the country. Here it is important to note that the initial determinations made by the respective offices of the information commissioners involved were called into question in all three cases. In the Criminal Lawyers' Association case, the Supreme Court of Canada found that the Assistant Commissioner of the office of the Ontario Information and Privacy Commissioner failed to examine whether the government decision-maker had considered the public interest in disclosing the information requested. In Attaran, the Federal Court of Appeal found that there was no evidence that supported that the government decision-maker had properly exercised his discretion under the Act, despite the fact that the office of the Information Commissioner of Canada had found that the exercise of discretion to refuse disclosure pursuant to section 15 of the Access Act was reasonable.

Finally, in Bronskill, Justice Nöel of the Federal Court found a complete lack of evidence supporting the government's claim that it had exercised its discretion under section 15 of the Access Act, despite the fact that the Information Commissioner of Canada had concluded that the exercise of discretion under section 15 was reasonable. In particular, Justice Nöel stated:

It is also surprising, if not worrisome, that the Information Commissioner found that LAC's initial withholding of information could solely be justified under section 15 of the Act. Clearly, the scope of section 15 of the Act was exceeded in both reviews of the documentation, as well as in the Information Commissioner's review of the documents. ${ }^{100}$

Justice Nöel further noted that there was no evidence that the Information Commissioner engaged in a thorough investigation involving probing questions. Justice Nöel admonished the Information Commissioner, writing: “The Commissioner must not be dazzled by the 
claims made based on national security as a thorough and independent review must be undertaken with a critical mind, in keeping with the legislative objectives at play."101

It is difficult to trace the impact of these decisions on the activities of the federal Information Commissioner at this stage due to the fact that the federal Commissioner does not have order-making power under the Access Act. As a result, when the Commissioner investigates complaints concerning refusals to disclose information, the Commissioner does not make orders supported by reasons concerning the government's decision to refuse disclosure. Rather, where the Commissioner finds that the refusal to disclose is not justified under the Access Act, the Commissioner provides the department with recommendations to disclose. ${ }^{102}$ If the government continues to refuse to disclose the information, the decision to refuse disclosure may then become subject to judicial review by the Federal Court. ${ }^{103}$

As a result, it may still be some time before we have judicial decisions that allow us to objectively assess whether the Information Commissioner of Canada has heightened her own level of scrutiny when it comes to claims by government officials that they have properly exercised their discretion under the Access Act. That being said, the Information Commissioner of Canada does provide a summary of notable cases that have been resolved by her office in her annual reports. The most recent reports suggest that the Commissioner has been actively requiring government departments to provide appropriate explanations to support the exercise of administrative discretion to refuse disclosure of information. ${ }^{104}$

More tangible evidence is available concerning the actions of provincial access to information adjudicators. In particular, the review of recent decisions taken by access to information adjudicators in Ontario and Alberta in Part III of this article demonstrate that front-line adjudicators in those jurisdictions are following the example set in the Criminal Lawyers' Association decision and specifically that these adjudicators are actively questioning whether decision-makers have considered the public interest in disclosure of information at issue when exercising their discretion to refuse disclosure. These cases also indicate that, while the evidence required to satisfy this inquiry may vary based on the circumstances, the use of bald claims of proper exercise of the discretion will be found insufficient.

\section{CONCLUSION}

Was there an attempt to cover-up potential abuse of power by police and Crown attorneys in a case that led to a stay of charges against two alleged assassins? Did Canadian armed forces turn over detainees to officials who torture their prisoners? Did Canadian police and intelligence officers abuse their powers to spy on a prominent politician? The answers to these questions, and others like them, are key to maintaining accountability of state officials in our democracy. They cannot be answered without access to government records. Yet access to those records is too often restricted by government officials exercising discretionary powers to refuse disclosure. 
While legislative exemptions from disclosure requirements have been established in order to facilitate effective governance, the challenge is to ensure that the government officials who respond to access to information requests only rely upon these exemptions in justifiable circumstances. The challenge is great. Explanations for the failure to comply with legislative disclosure requirements may range from willful disobedience, to inefficient or careless processing of access requests, to improper interpretation of the scope of legislative exemptions, or a combination of these and other factors.

One of the keys to ensuring the proper administration of legislative access regimes is active review of discretionary decisions taken under those regimes. The decisions in Criminal Lawyers' Association, Attaran, and Bronskill indicate that Canadian judges are prepared to engage in active review of the exercise of discretion under access legislation within an administrative law context. While respecting the fact that the exercise of discretion by administrative officials under access to information regimes should be reviewed under a reasonableness standard, these decisions have signaled that Canadian courts will nonetheless have high expectations of government officials relying on discretionary exemptions under access legislation.

In particular, the Supreme Court of Canada's decision in Criminal Lawyers’ Association has clearly articulated the requirement for government officials to consider the public interest in disclosure of the information at issue in addition to any public interest in refusing to disclose the information. In addition, the decisions reviewed in this article have emphasized the requirement of evidence to support claims made by government officials that they have properly exercised their discretion not to disclose information pursuant to access legislation. Thus, the Supreme Court found the failure to provide reasons for the refusal to disclose information and the failure to disclose a single page in a lengthy record, raised doubts concerning whether the government decision-maker had adequately exercised his discretion. Similarly, the Federal Court of Appeal in Attaran explicitly noted that bald statements claiming the discretion has been exercised are insufficient evidence of the exercise of discretion.

Where government officials rely on discretionary exemptions based on a reasonable likelihood of harm from disclosure, courts have emphasized the need for clear and precise evidence to support both the reasonableness of the finding of a likelihood of harm and the reasonableness of the exercise of discretion. This evidence should be specific, not general, and should be directly linked to the alleged injury justifying exercise of discretion not to disclose. Finally, courts have indicated that the burden to prove that the exercise of discretion has been exercised reasonably will shift to the party claiming the exemption where the applicant cannot access either the information at issue or the evidence relied upon to support the refusal to disclose.

Admittedly, the evidentiary requirements articulated in Criminal Lawyers' Association, Attaran, and Bronskill are far from intrusive. In many cases, the exercise of discretionary powers to refuse disclosure of government information will be upheld despite the absence of conclusive evidence that the decision-maker has adequately considered the public interest in disclosure of the information. Such is the nature of the limitations on judicial review of discretionary powers. 
Nonetheless, by adopting an active (as opposed to overly deferential) approach to the review of the exercise of discretion under access regimes, the decisions discussed in this article have ensured that some light will be shone on the ways in which discretion to refuse disclosure of government information is exercised. Where this light reveals the failure to consider relevant factors, including the public interest in disclosure of the information at issue, decision-makers will be forced to reconsider their decisions while taking the proper factors into account. In the end, by shining more light on these decisions, judges will ensure more access to government information. As such, these decisions mark an important affirmation of the ways in which judges can continue to promote our rights of access to government information under existing access regimes as we continue the long wait for legislative reform. 